\title{
Food Allergy and the Oral Immunotherapy Approach
}

\author{
Carmen M. Cabrera $\cdot$ José M. Urra
}

Received: 1 February 2014/ Accepted: 15 May 2014/Published online: 16 July 2014

(C) L. Hirszfeld Institute of Immunology and Experimental Therapy, Wroclaw, Poland 2014

\begin{abstract}
Food allergy represents an increasing health problem, with children being the most affected population. The symptoms can appear within minutes or hours of ingesting the offending food, producing skin manifestations, respiratory, gastrointestinal and anaphylactic reactions in the severe forms. Food allergy is established by the loss of tolerance to food proteins, and is characterized by an altered balance of regulatory $\mathrm{T}$ (Treg) cells and the shift to Th2 type cytokines in the intestinal lamina propria. We have described the contribution of different factors in establishing oral tolerance, such as the antigenic exposition route, the gut microenvironment, and the timing of the food introduction. Apart from avoiding the food, immunotherapy is the only intervention which produces oral desensitization to food proteins. Among the underlying immunological mechanisms of oral immunotherapy (OIT) are the changes in humoral immunity (a decrease of allergen-specific IgE and an increase of allergen-specific IgG4) and cellular changes such as the increased number of FoxP $^{+}$Treg cells. At present, the experiences of OIT with various foods are offering promising results. OIT appears to be safe producing low adverse reactions, and effective in inducing desensitization in most subjects with food allergy.
\end{abstract}

Keywords Allergy - Food - Immunologic mechanisms · Oral tolerance $\cdot$ Oral immunotherapy

C. M. Cabrera $(\bowtie) \cdot$ J. M. Urra

Immunology Section, Hospital General Universitario de Ciudad Real, Avda. Obispo Rafael Torija s/n, 13005 Ciudad Real, Spain e-mail: carmenmcabrera@gmail.com

\section{Introduction}

A food allergy is defined as an adverse immune response to food protein, mainly mediated by type I hypersensitivity reactions upon food intake (Sicherer and Sampson 2010). They are characterized by early symptoms that usually appear within minutes or up to $2 \mathrm{~h}$ after ingestion; they include urticaria, angioedema, rhinoconjunctivitis, asthma, gastrointestinal symptoms and anaphylactic reactions (Mansoor and Sharma 2011).

Currently, food allergy represents a serious health problem, as has been noted in recent years, with increasing rates of incidence among children in advanced countries. For example, allergies to the peanut tripled in incidence between 1997 and 2008 in the USA and the UK (Hourihane et al. 2007; Sicherer et al. 2010). However, in the cohort studies carried out this increasing rate not appear to be real, showing similar data of prevalence over time (Ben-Shoshan et al. 2009; Venter et al. 2010). Therefore, the so-called increase in the prevalence of food allergy must be taken with caution because of sampling and population composition. Although food allergies are reported in the general population, they are more prevalent in young people with 6-8 \% incidence compared to $3-4 \%$ in adults (Mansoor and Sharma 2011). Similarly, common food allergies in children differ from those in adults (Table 1) (Sicherer and Sampson 2010). More than $90 \%$ of food allergies are due to eight main foods: milk, egg, peanut, tree nut, soy, wheat, fish and shellfish (Venter and Arshad 2011).

Allergy to cow's milk is the commonest food allergy among infants and young children, affecting approximately $2.5 \%$ of children younger than 3 years old (Crisafulli et al. 2012). Egg allergy is the second most frequent food allergy in childhood $(1.5 \%)$, followed by peanut allergy which affects $1.4 \%$ of children (Frazier et al. 2014). 
Table 1 Estimated food allergy rates in North America

\begin{tabular}{lll}
\hline Prevalence & Infant/child $(\%)$ & Adult $(\%)$ \\
\hline Milk & 2.5 & 0.3 \\
Egg & 1.5 & 0.2 \\
Peanut & 1 & 0.6 \\
Tree nuts & 0.5 & 0.6 \\
Fish & 0.1 & 0.4 \\
Shellfish & 0.1 & 2 \\
Wheat, soy & 0.4 & 0.3 \\
\hline
\end{tabular}

Peanut allergy is often very severe, with the most frequent rate of anaphylactic reactions compared to milk and egg (Rutkowski et al. 2012). It is also, a lifelong allergy, because only $20 \%$ of children will outgrow their peanut allergy (Sicherer and Sampson 2007). This is in contrast to egg and milk allergies, in which up to $80 \%$ of children will outgrow their allergy developing spontaneous tolerance (Sampson 2004).

Currently, the only treatment for food allergy consists of strict food avoidance, dietary management to avoid nutritional deficiencies, and rapid emergency treatment in response to an anaphylactic reaction. The diagnostic tests available at present (allergen-specific $\operatorname{IgE}$ (sIgE) antibodies and skin prick tests) which determine the sensitization grade is not able to predict future food reactions and their severity (Eigenmann et al. 2011). Neither can these tests distinguish between subjects with transient food allergies and those with persistent forms. In spite of this, although there is some evidence to support that skin prick test (SPT) and SIgE may predict which children could outgrow their food allergy, it not appears to be sufficient for the use of a particular threshold as a marker of transient or persistent allergy (Peters et al. 2013). Therefore, the therapeutic interventions for food allergy represent an alternative therapy aimed at improving the quality of life of the patients, particularly in cases of persistent food allergy and with a history of repeated anaphylactic reactions. These therapies are able to change the natural course of food allergy when it is persistent, to bring forward tolerance, that is loss of immune response to harmless gut antigens, or at least to produce desensitization that avoids the reactions caused by the accidental intake. The immunological approaches to food allergy interventions that are now been investigated include among others: oral immunotherapy (OIT), sublingual immunotherapy and epicutaneous immunotherapy (Nowak-Wegrzyn and Muraro 2011; Scurlock and Jones 2010).

The first report on OIT was published by Patriarca et al. (2003), in a standardized protocol for the treatment of various food allergies they obtained a success rate of $77 \%$. Since then, many studies on OIT have been reported, primarily for milk, egg and peanut allergies. The variety of proposed protocols makes it difficult to compare results between them. However, all of them consist of desensitization regimens by the oral administration of increasing doses of the food, until a normal ration is well tolerated or at least an enough amount to protect from an accidental or inadvertent ingestion. At present, OIT for food allergy is the most actively investigated therapeutic approach.

\section{Pathophysiology of Food Allergy}

A food allergy is characterized by a dysregulation of the Th2 type response to harmless food proteins due to a failure of oral tolerance, mainly producing an increase in the serum levels of $\operatorname{sIgE}$ to food allergens and a type I hypersensitivity reaction (Beyer et al. 2002; Wambre et al. 2012). However, two steps are required for an IgE-mediated hypersensitivity reaction to take place: the primary sensitization process and the oral challenge (Vickery et al. 2011).

The overrepresentation of peanut and tree nut allergies among cases of fatal food-induced anaphylaxis further supports the concept that certain foods tend to be more allergenic than others (Bock et al. 2007). However, the main food allergens (milk, egg, peanut, tree nut, soy, wheat, fish, and shellfish) in spite of their diverse origins have common characteristics: (a) a relatively small molecular weight, ranging 10-70 kDa, they are (b) glycoproteins, (c) water soluble, and (d) stable to heat and digestion (Bannon 2004).

Most proteins ingested in the diet are broken down to amino acids by the action of proteolytic enzymes during digestion, however, $2 \%$ of the proteins we ingest remain completely intact and are capable of inducing an immune response (Husby et al. 1985; Sicherer and Sampson 2010). The allergenic proteins must reach the lamina propria and contact with the immune cells of the gut-associated lymphoid tissue to initiate an immune response. First, the allergenic proteins cross the epithelial gut layer by one of the following mechanisms: by microfold cells that overlie Peyer's patches; direct sampling by dendritic cells (DCs) that extend their dendrites to the epithelial surface; and by transcellular or paracellular transport across the epithelial cells (Burks et al. 2008; Chehade and Mayer 2005).

Once the allergenic proteins cross the epithelial layer they are captured by DCs in the lamina propria. The proteins are then internalized and degraded to peptides which are presented by $\mathrm{MHC}$ class II molecules to naive $\mathrm{CD} 4^{+} \mathrm{T}$ cells. The naive $\mathrm{CD} 4^{+} \mathrm{T}$ cells, in the presence of an adequate milieu of cytokines as interleukin (IL)-4 (significant amounts of IL-4, IL-5 and IL-13), differentiate into allergen-specific Th2 cells. How this proallergic milieu 
Fig. 1 FceRI structure on mast cells and basophils. The crosslinking of sIgE-FceRI complexes by allergens target the intracellular signaling events initiated by tyrosine kinase. The phosphorylation cascade leads to intracellular $\mathrm{Ca}^{2+}$ release from endoplasmic reticulum and degranulation with release of preformed mediators (histamine, heparin, tryptase, etc.). Moreover, the phosphorylation activates the synthesis and release of cytokines and lipid mediators from arachidonic acid metabolism (prostaglandins and leukotrienes)

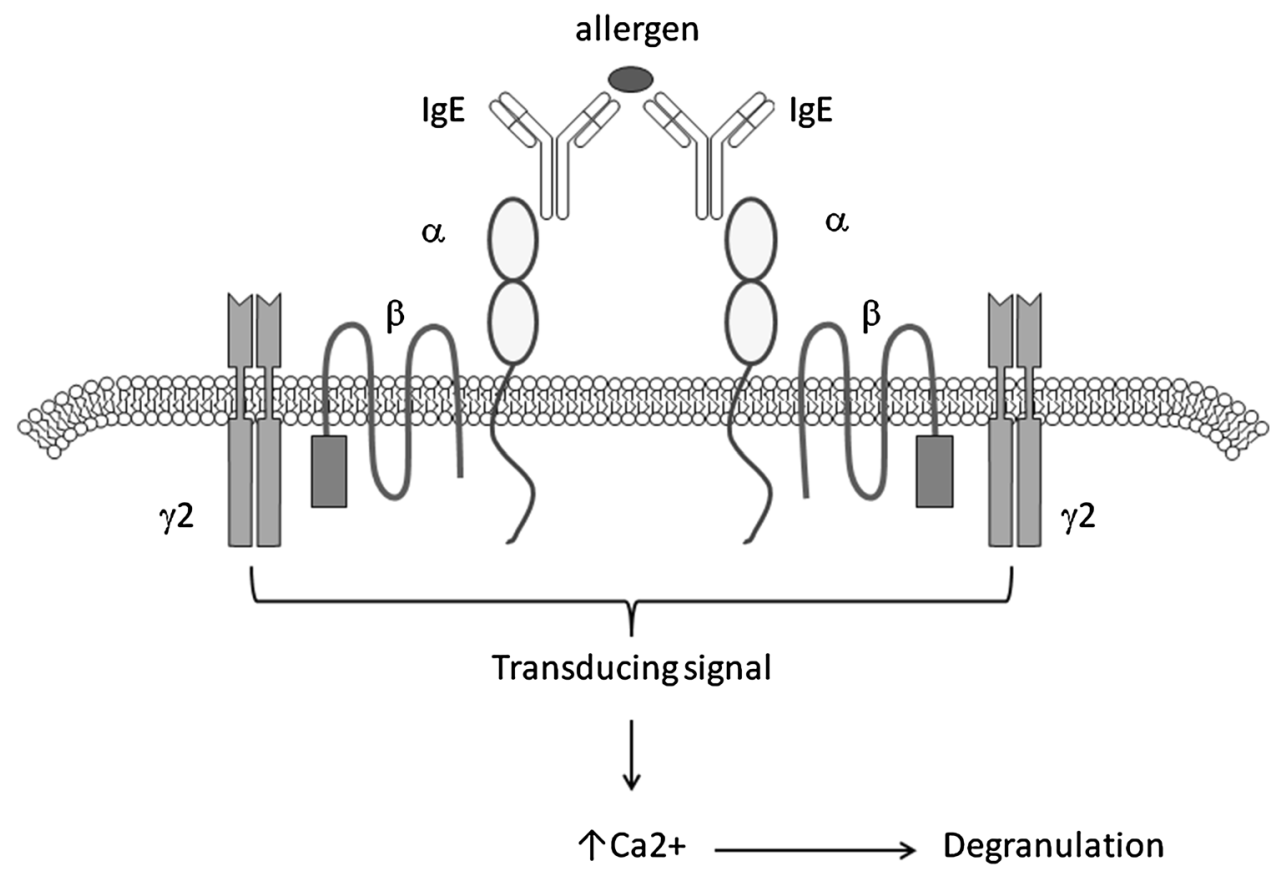

develops in a naive subject is a yet unresolved question. The interaction of theses allergen-specific Th2 cells with allergen-specific B cells induces antibody class switching to $\operatorname{IgE}$ (Sicherer and Sampson 2010).

DCs have innate and adaptive receptors on their surfaces for the recognition and internalization of allergenic proteins (Sharquie et al. 2013). Innate receptors include C-type lectins, such as the mannose receptor and DC-SIGN which recognize carbohydrate residues in the allergenic proteins. So, in an in vitro study DC-SING has been described as the receptor for the major peanut allergen Ara h 1 (Shreffler et al. 2006). The adaptive receptors are the high-affinity receptor (FceRI), and the low-affinity receptor (FceRII or CD23) for IgE antibodies (Dhaliwal et al. 2013). FceRI is a tetrameric form $\left(\alpha \beta \gamma_{2}\right)$, with an IgE-binding $\alpha$-chain, a $\beta$ chain, and a homodimeric $\gamma$-chain, in addition to DCs, it is the major receptor in mast cells and basophils (Fig. 1). In addition, CD23 is expressed in B cells that can bind allergen-IgE complexes in the periphery or at the mucosal surface and facilitate allergen presentation.

The production of sIgE by B cells is a highly efficient process that supports allergen processing and the presentation of allergenic peptides to allergen-specific Th2 cells. In the allergen processing, allergen-immunoglobulin and allergen-IgE-CD23 complexes are internalized on the surface of B cells and transported to endosomes. This process is followed by loading of allergen-derived peptides onto MHC-II molecules and presentation to Th2 cells, by the way of T cell receptors (Oliphant et al. 2011) (Fig. 2). Besides the interaction between $B$ cells and Th2 cells, for B-cell activation and isotype switching three signals are also required and they are mediated by: (a) CD40L on Th2 cells and CD40 on B cells, (b) the CD28 costimulatory signal on Th2 cells and CD80/CD86 on B cells, and (c) the cytokines IL-4 and IL-13 released by activated Th2 cells (Fig. 2).

The preformed sIgE antibodies are then bound to FceRI receptors on mast cells and basophils. After re-exposition to allergens, the cross-linking of sIgE-FceRI complexes on mast cells and basophils by multivalent allergens will activate the release of the mediators (Fig. 1).

In food allergy, mast cells located in lamina propria are mainly responsible for the release of mediators. These include: (a) preformed mediators in the form of the cytoplasmic granules: histamine, heparin, tryptase and others; (b) lipid mediators, such as prostaglandin D2 and leukotrienes, derived from arachidonic acid metabolism via cyclooxygenase or 5-lipoxygenase, respectively, and platelet activator factor; and (c) newly or preformed cytokines: tumor necrosis factor- $\alpha$, IL-4, IL-3, IL-5, etc. (Fig. 1). These mediators are able to induce smooth muscle contraction, while increasing vascular permeability, leukocyte recruitment and mucus secretion. These alterations may also occur very vigorously leading to anaphylactic reactions.

\section{Contributing Factors to Oral Tolerance}

Tolerance, defined as the loss of reactivity to an antigen or allergen, is a permanent immunological state in which infrequent or repeated antigen exposures do not result in an 


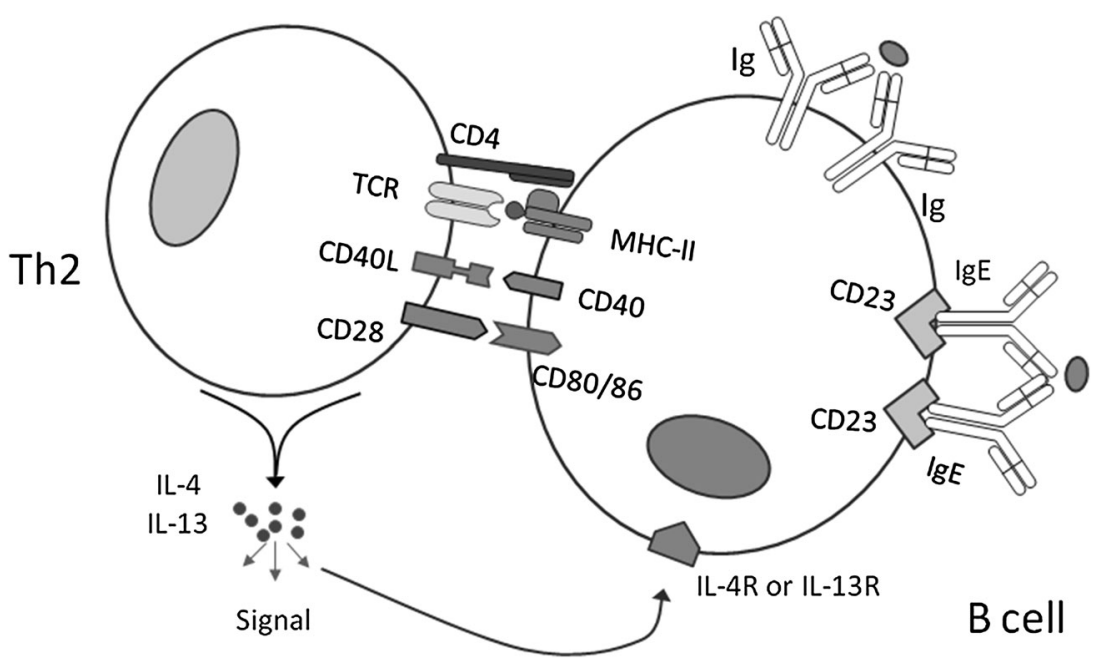

Fig. $2 \mathrm{~B}$ cell activation and isotype switching to allergen-sIgEproducing B cells. Cross-linking of membrane-Ig and CD23-IgE complexes by allergens target their internalization and processing in B cells. Subsequently, allergenic peptides are presented by the MHC-
II molecules to T-cell receptors (TCRs) in Th2 effector cells. In addition, this interaction between $\mathrm{B}$ cells and $\mathrm{Th} 2$ cells requires signaling through CD40L/CD40, CD28/CD80, CD86 costimulatory molecules and IL-4/IL-13 cytokines produced by activated Th2 cells allergic reaction (van Wijk and Knippels 2007). The tolerogenic state to oral antigens in a healthy subject is characterized by a predominance of regulatory $\mathrm{T}$ (Treg) cells in the intestinal lamina propria. Conversely, in a subject with a food allergy there is an altered balance with a skewing to Th2 effector cells. Different factors have been implicated in the establishment of oral tolerance to harmless antigens present in the diet. These include, among others: the route of antigen exposure for the sensitization process, antigenic dose, a failure in the induction of Treg cells, the gut commensal bacteria and the timing of the introduction of solid foods.

The gut-associated lymphoid tissue is the primary route by which we are exposed to antigens. However, in the case of food allergy, evidence has been presented which relates to other routes that are responsible for allergen sensitization. In this sense, it was found that more than one-half of the patients with egg allergy developed clinical manifestations between 6 and 12 months of age, when egg was first introduced into the diet (Martorell et al. 2013). Similarly, the majority of children develop peanut or tree nut allergy following their first ingestion (Brough et al. 2013; Ewan 1996; Lack et al. 2003). Thus, a previous sensitization process by a non-oral route takes place in these subjects. It is possible that the contact of proteins with the immune cells by routes different from the gut could be implied in the failure to establish oral tolerance. Other suggested routes of allergen exposure include through breast milk, via inhalation, across the skin, the first contact could even occur through the placenta during fetal development (Berin and Sampson 2013). However, the most likely route for the allergenic sensitization to food is across the skin. This is supported by the finding that peanut-responsive $\mathrm{T}$ cells in peanut allergic patients mainly express the skin homing receptor known as cutaneous lymphocyte antigen (Chan et al. 2012). In addition, it has been found that the Ara $h$ 1 -specific $\mathrm{T}$ cells identified by tetramer staining express high levels of the chemokine receptor CCR4, a Th2-associated cell trafficking marker into skin lesions (DeLong et al. 2011). In fact, the skin is the most frequent site of clinical symptoms of the food allergy after an oral food challenge (Ahrens et al. 2012), highlighting the need for a better understanding of the immune communication between gut and skin during sensitization and allergen reexposure (Berin and Sampson 2013).

The lamina propria DCs play a primary role in the process of sensitization to allergenic proteins. DCs act as "professional" antigen-presenting cells (APCs) to naive $\mathrm{CD} 4^{+} \mathrm{T}$ cells, which in the appropriate milieu of cytokines are differentiated into $\mathrm{CD} 4^{+}$effector cells and $\mathrm{CD} 4^{+}$Treg cells in the mesenteric lymph nodes (MLNs). The balance of effector and Treg cells in the gut appears to regulate the tolerance to food allergens. So, the failure to induced Treg (iTreg) cells at the lamina propria is implicated in the development of food allergies (Karlsson et al. 2004; Shreffler et al. 2009). Treg cells are characterized by the expression of the forkhead transcription factor FoxP3. Two major subsets of $\mathrm{FoxP}^{+}$Treg have been identified: the naturally occurring $\mathrm{CD} 4{ }^{+} \mathrm{CD} 25^{+}$Treg cells that arise in the thymus and the tumor necrosis factor (TGF)- $\beta$-iTreg cells produced in the periphery (Zhou et al. 2009). The induction of $\mathrm{CD} 4{ }^{+} \mathrm{CD} 25^{+}$Treg in the gut takes place in the MLNs by the primed CD103 ${ }^{+}$DCs. The $\mathrm{CD} 103^{+}$DCs have tolerogenic proprieties upon priming of allergenic 
proteins in the lamina propria, they migrate to MLNs and produce TGF- $\beta$ and retinoic acid which activate the synthesis of FoxP3 in the naive $\mathrm{CD}^{+}{ }^{\mathrm{T}}$ cells and their differentiation into iTreg (Pabs and Mowat 2012; Scott et al. 2011). Conversely, the other subset of lamina propria DCs, the CD103- DCs are strongly proinflammatory and induce the differentiation of naive $\mathrm{CD} 4^{+} \mathrm{T}$ cells into Th1/ Th17 cells (Scott et al. 2011). Furthermore, it has been reported that the TGF- $\beta$-induced iTreg cells present flexibility in their differentiation, thus depending on the cytokine milieu they can differentiate into proinflammatory Th17 cells (Nakayamada et al. 2012; Zhou et al. 2009). The Th17 cells can also, in the appropriate cytokine ambient, differentiate into Th1 and Th2 effector cells (Nakayamada et al. 2012; Zhou et al. 2009). Therefore, the microenvironment of the lamina propria has a central role in the cellular fate of the naive $\mathrm{CD} 4^{+} \mathrm{T}$ cells, controlling the balance of regulatory versus inflammatory $\mathrm{T}$ cells and the tolerance of the proallergic state.

It is also likely that the commensal gut flora also play a role in oral tolerance induction, as initially suggested by the observation that mice raised in a germ-free environment do not have normal tolerance. Similarly, it has been reported that mice treated with antibiotics to reduce the gut flora or lacking Toll-like receptor 4 and which were then exposed to a sensitizing regimen of peanut were more prone to peanut allergy than wild-type control animals (Bashir et al. 2004; Sudo et al. 1997). About human studies there are no compelling data to show an association between the use of antibiotics and food allergies because the reports are limited and the results are conflicting (Dowhower Karpa et al. 2012; Metsälä et al. 2013).

Another factor that influences the establishment of oral tolerance is the timing of the introduction of solid foods in infants. The human neonatal gut is immature and breast milk contains several functional nutrients that provide the microenvironment for gut protection and maturation (Sansotta et al. 2013). Delays in either the colonization or in antigen exposure can lead to failure of oral tolerance (Poole et al. 2006). Conversely, too early an exposure to allergens, when gut colonization and local immune networks are less established, may increase the risk of allergic (Fergusson et al. 1990; Sausenthaler et al. 2011) or autoimmune diseases (Halken and Høst 1996). Therefore, in the oral tolerance induction there is a critical "window period" to reduce the risk of allergy. Although the timing of this window to prevent allergies is not completely clear, current evidence suggests that this is most likely to be located between the 4th (around 17 weeks) and the 7th month of life (Prescott et al. 2008). In this regard, Koplin et al. (2010) have found that infants who were introduced to cooked egg at 4-7 months had the lowest risk of developing an allergy to eggs. The authors pointed to the new concept of a window during which exposure to potentially allergenic foods will promote the development of oral tolerance.

\section{Mechanisms of OIT in Food Allergy}

The OIT intervention to food allergy is based on the administration of increasing antigenic food doses to induce a desensitization process and/or tolerance. Desensitization is defined as the change in the threshold dose of ingested food allergen necessary to cause allergic symptoms. In contrast, tolerance is the induction of long-term immunologic changes associated with the ability to ingest a food without symptoms and without any therapy.

The usual approach to OIT involves an initial dosage escalation phase followed by a daily maintenance dose, coupled with a final oral food challenge (OFC) to evaluate the therapeutic effect. These protocols are usually carried out between 6 and 12 months. The starting dose is sufficiently low to be well tolerated by all patients. The dose of the food is periodically increased (several doses in a day, daily, weekly or every 15 days) to reach the maximum dose in a reasonable time with the minimum number of reactions. The goal would be, at least, to protect allergic children from an accidental ingestion of the food or, ideally, to allow the patient to perform a normal diet with the food. Different protocols for OIT have been reported mainly for milk, egg and peanut allergies, in which the daily maintenance dose is attained after weeks or months (conventional protocols) or days (rush protocols). Most of these protocols have proven effective and between 36 and $94 \%$ of children achieved tolerance to at least enough amount of the food to be protected from an inadvertent ingestion (Wang and Sampson 2013). These protocols often cause adverse reactions which, not infrequently, occur in all patients (Niggemann et al. 2006; Burks et al. 2012). Although most of the reactions are mild, moderate reactions are not exceptional (Burks et al. 2012). The rate of desensitization reached at the end of the OIT protocols with OFC, ranged 36-90\% for milk allergy, $86 \%$ for egg allergy, and $94 \%$ for peanut allergy (Wang and Sampson 2013).

The humoral mechanisms underlying the desensitization process observed upon immunotherapy to aeroallergens include the decrease of allergen-sIgE and the increase of allergen-specific IgG4 antibodies (Shamji and Durham 2011; Shamji et al. 2011). Moreover a decrease in the number of mast cells and basophils, determined by the SPT and the basophil activation test (BAT), respectively, has been observed in immunotherapy for aeroallergens (Gokmen et al. 2012; Plewako et al. 2006). Similarly, in food allergies treated with OIT protocols for milk, egg, and peanut, decreases in the serum levels of SIgE, SPTs, BATs 
Table 2 Mechanisms of OIT in food allergy for milk, egg and peanut

\begin{tabular}{|c|c|c|c|}
\hline Immunologic changes & Milk & Egg & Peanut \\
\hline$\downarrow \mathrm{SPT}$ & $\begin{array}{l}\text { Narisety et al. (2009) }(N 15, \mathrm{SR} \\
80 \%) \\
\text { Martorell et al. (2011) }(N 30, \mathrm{SR} \\
\quad 90 \%)\end{array}$ & $\begin{array}{l}\text { Vickery et al. (2010) ( } N \text { 7, SR } 57 \%) \\
\text { García Rodríguez et al. (2011) ( } 23 \text {, SR } \\
\quad 86.9 \%)\end{array}$ & $\begin{array}{l}\text { Jones et al. (2009) (N 29, SR } \\
\quad 93 \%) \\
\text { Varshney et al. (2011) (N 19, SR } \\
\quad 84 \%)\end{array}$ \\
\hline$\downarrow^{\mathrm{a}}=$ Allergen-specific IgE & $\begin{array}{l}\text { Longo et al. (2008) ( } N 30, \mathrm{SR} \\
80 \%) \\
\text { Narisety et al. (2009) ( } N \text { 15, SR } \\
80 \%) \\
\text { Martorell et al. (2011) ( } N 30, \mathrm{SR} \\
90 \%) \\
\text { aSkripak et al. (2008) ( } N 20, \mathrm{SR} \\
92 \%) \\
{ }^{\text {a} P a j n o ~ e t ~ a l . ~(2010) ~(N ~ 30, ~ S R ~} \\
76 \%)\end{array}$ & $\begin{array}{l}\text { Vickery et al. (2010) ( } 7 \text {, SR } 57 \%) \\
\text { García Rodríguez et al. (2011) (N 23, SR } \\
\quad 86.9 \%)\end{array}$ & $\begin{array}{l}\text { Jones et al. (2009) ( } N 29, \mathrm{SR} \\
\quad 93 \%)\end{array}$ \\
\hline$\uparrow$ Allergen-specific IgG4 & $\begin{array}{l}\text { Narisety et al. (2009) ( } N 15, \mathrm{SR} \\
\quad 80 \%) \\
\text { Skripak et al. (2008) (N 20, SR } \\
\quad 92 \%) \\
\text { Pajno et al. (2010) (N 30, SR } \\
\quad 76 \%)\end{array}$ & $\begin{array}{l}\text { Vickery et al. (2010) ( } N \text { 7, SR } 57 \%) \\
\text { García Rodríguez et al. (2011) ( } 23 \text {, SR } \\
\quad 86.9 \%)\end{array}$ & $\begin{array}{l}\text { Jones et al. (2009) (N 29, SR } \\
\quad 93 \%) \\
\text { Varshney et al. (2011) } \\
(N 19, \text { SR } 84 \%)\end{array}$ \\
\hline$\downarrow$ BAT & $\begin{array}{l}\text { Ford et al. (2013) (N 132, SR } \\
\quad 65 \%)\end{array}$ & Burks et al. (2012) (N 40, SR $55 \%)$ & $\begin{array}{l}\text { Jones et al. (2009) ( } N 29, \text { SR } \\
\quad 93 \%)\end{array}$ \\
\hline$\uparrow$ IL-10/TGF- $\beta$ & ND & $\begin{array}{l}\text { Vickery et al. (2010) }(N 7, \text { SR } 57 \%) \\
\text { Itoh et al. (2010) }(N 6 \text {, SR } 100 \%)\end{array}$ & $\begin{array}{l}\text { Jones et al. (2009) ( } N 29, \mathrm{SR} \\
\quad 93 \%)\end{array}$ \\
\hline $\begin{array}{l}\downarrow \text { Th2 type cytokines (IL-5 and } \\
\text { IL-13) }\end{array}$ & ND & ND & $\begin{array}{l}\text { Blumchen et al. (2010) (N 23, SR } \\
\quad 95 \%) \\
\text { Varshney et al. (2011) (N 19, SR } \\
\quad 84 \%)\end{array}$ \\
\hline$\uparrow$ FoxP3 $^{+}$Treg & ND & Urra et al. (2012) ( $N 20$, SR $90 \%)$ & $\begin{array}{l}\text { Jones et al. (2009) (N 29, SR } \\
\quad 93 \%) \\
\text { Varshney et al. (2011) (N 19, SR } \\
\quad 84 \%)\end{array}$ \\
\hline
\end{tabular}

$B A T$ basophil activation test, $N$ number of subjects enrolled in the study, $N D$ not determined, $S P T$ skin prick test, $S R$ success rate of desensitization

${ }^{\text {a }}$ Not decreased sIgE levels

and increase of allergen-specific IgG4 after 3-6 months of treatment have been reported (Table 2). However, in two OIT protocols for milk allergy no differences were observed in the serum levels of sIgE (Pajno et al. 2010; Skripak et al. 2008) (Table 2). Specifically, in the study of Skripak et al. (2008) twenty children were studied in a double blind and placebo assay, with a success rate of $92 \%$ upon OIT to milk in the active group (13 patients). Equally, Pajno et al. (2010) carried out a double blind and placebocontrolled trial for OIT to milk, in 30 children obtained a $76 \%$ of tolerance upon OFC in the active group (15 patients). Moreover, in both studies, an increase in the serum levels of sIgG4 to milk was observed in the group of active patients (Table 2).

Allergen-specific IgG4 antibodies to aeroallergens have been shown to act as blocking antibodies, that is, they are able to compete with sIgE for allergen binding (van Neerven et al. 1999; Wachholz et al. 2003). Thus, these antibodies produce an inhibition of the release of mediators from mast cells and basophils. In addition, the IgG4 antibodies to aeroallergens can produce a decrease in the processing and presenting activity of the APCs (DCs and B cells) thereby inhibiting the binding of allergen-IgE complexes to CD23 (van Neerven et al. 1999; Wachholz et al. 2003). In a similar way, in patients with peanut allergy the IgE-facilitated allergen binding assay has noted the possibility that these $\operatorname{sgG} 4$ antibodies have a functional role in the inhibition of CD23-medited presentation by B cells to $\mathrm{T}$ cells (Jones et al. 2009).

Another change that has been reported in immunotherapy to aeroallergens is the production of the immunosuppressive cytokine IL-10 from peripheral blood 
Fig. 3 Humoral and cellular mechanisms induced by OIT protocols for food allergens. $B A T$ basophil activation test, PBMCs peripheral blood mononuclear cells, and SPT skin prick test

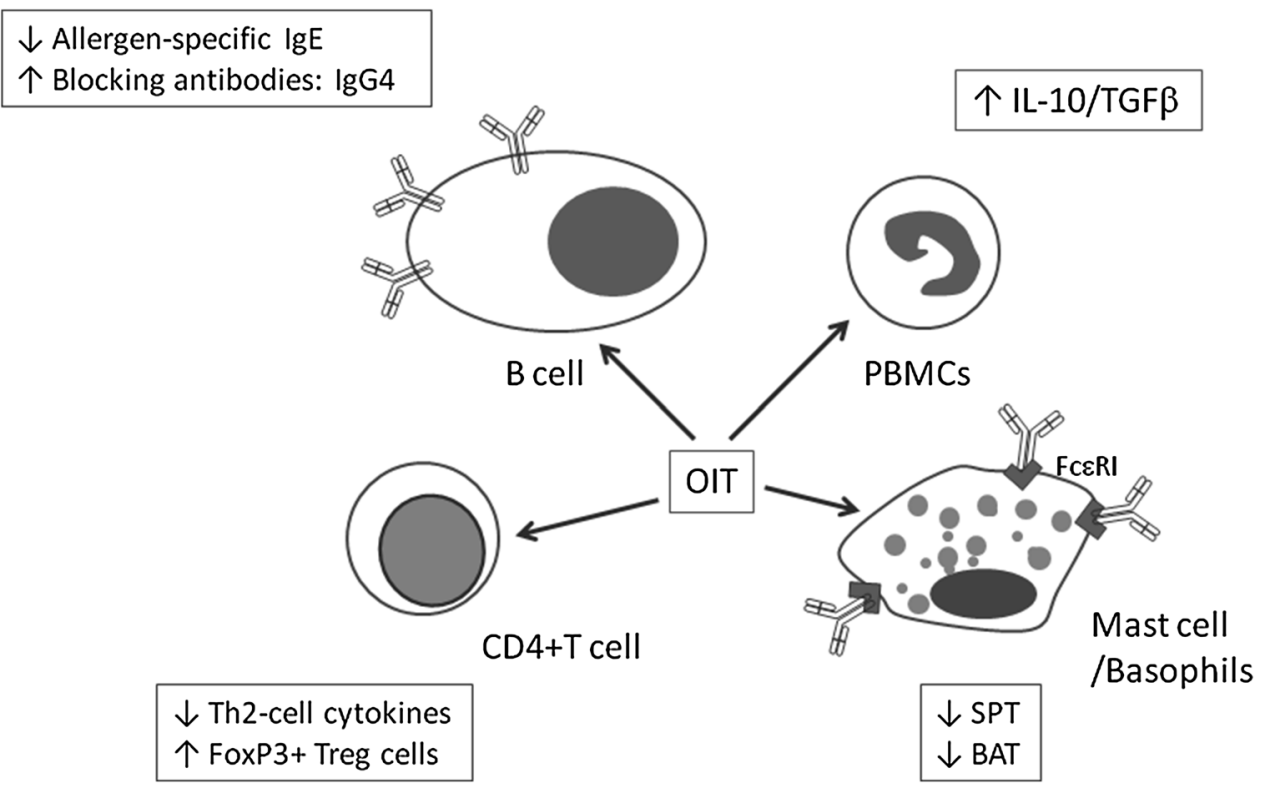

mononuclear cells (PBMCs) (Francis et al. 2008). However, in OIT protocols for food allergy have been reported the production of IL-10 and/or TGF- $\beta$ from PBMCs (Table 2). Both immunosuppressive cytokines have a primary role in maintaining tolerance, presenting different actions above the suppression of cellular and humoral responses. They are able to suppress the production of sIgE, the migration of mast cells, basophils and eosinophils to tissues, and produce immunoglobulin class switching to IgG4 among other functions (Wambre et al. 2012).

The establishment of long-term tolerance upon immunotherapy to aeroallergens is highlighted by the increase of allergen-specific IL-10/TGF- $\beta$ producing $\mathrm{FoxP}^{+}$Treg (Francis et al. 2003; Ling et al. 2004) and the shift in the ratio of Th2/Th1 type cytokines (Faith et al. 2003; Jutel et al. 2003). In egg and peanut allergies, OIT protocols have been reported with an in vitro increase of FoxP3 ${ }^{+}$ Treg from PBMCs after 3 weeks and 6 months of treatment (Table 2). However, none of the OIT protocols to date have demonstrated an increase in Th1 type cytokines. Furthermore, the only description of low levels of Th2 type cytokines (IL-5 and IL-13) produced from PBMCs was reported in two OIT protocols for peanut allergy (Blumchen et al. 2010; Varshney et al. 2011). Figure 3 summarizes the immunological mechanisms of OIT for food allergies that have been described to date.

\section{Concluding Comments}

The majority of subjects in whom the OIT protocols for milk, egg and peanut allergies have been assessed presented desensitization to food allergens. However, the induction of long-term tolerance demonstrated by an increased production of FoxP3 ${ }^{+}$Treg cells from PBMCs and low levels of Th2 type cytokines have only been reported in a few OIT protocols (Table 2). Although desensitization protects against accidental ingestion and anaphylactic reactions, it is not enough to consider that these subjects present tolerance to allergenic foods. Therefore, the main objective of the OIT protocols, above that of desensitization, is to achieve a permanent tolerance by which the subjects will be protected for several years after treatment. Future investigations into OIT protocols are required to learn whether long-term tolerance can be induced, besides to a major knowledge of the patients who could benefit from theses protocols, those with a high risk of persistent allergy and severe anaphylactic reactions.

\section{References}

Ahrens B, Niggemann B, Wahn U et al (2012) Organ-specific symptoms during oral food challenge in children with food allergy. J Allergy Clin Immunol 130:549-551

Bannon GA (2004) What makes a food protein an allergen? Curr Allergy Astma Rep 4:43-46

Bashir ME, Louie S, Shi HN et al (2004) Toll-like receptor 4 signaling by intestinal microbes influences susceptibility to food allergy. J Immunol 172:6978-6987

Ben-Shoshan M, Kagan RS, Alizadehfar R et al (2009) Is the prevalence of peanut allergy increasing? A 5-year follow-up study in children in Montreal. J Allergy Clin Immunol 123:783-788

Berin MC, Sampson HA (2013) Food allergy: an enigmatic epidemic. Trends Immunol 34:390-395

Beyer K, Castro R, Birnbaum A et al (2002) Human milk-specific mucosal lymphocytes of the gastrointestinal tract display a $\mathrm{TH} 2$ cytokine profile. J Allergy Clin Immunol 109:707-713 
Blumchen K, Ulbricht H, Staden U et al (2010) Oral peanut immunotherapy in children with peanut anaphylaxis. J Allergy Clin Immunol 126:83-91

Bock SA, Munoz-Furlong A, Sampson HA (2007) Further fatalities caused by anaphylactic reactions to food, 2001-2006. J Allergy Clin Immunol 119:1016-1018

Brough HA, Santos AF, Makinson K et al (2013) Peanut protein in household dust is related to household peanut consumption and is biologically active. J Allergy Clin Immunol 132:630-638

Burks AW, Laubach S, Jones SM (2008) Oral tolerance, food allergy, and immunotherapy: implications for future treatment. J Allergy Clin Immunol 121:1344-1350

Burks AW, Jones SM, Wood RA et al (2012) Oral immunotherapy for treatment of egg allergy in children. N Engl J Med 367:233-243

Chan SM, Turcanu V, Stephens AC et al (2012) Cutaneous lymphocyte antigen and a4b7 T-lymphocyte responses are associated with peanut allergy and tolerance in children. Allergy 67:336-342

Chehade M, Mayer L (2005) Oral tolerance and its relation to food hypersensitivities. J Allergy Clin Immunol 115:3-12

Crisafulli G, Caminiti L, Pajno GB (2012) Oral desensitization for immunological E-mediated milk and egg allergies. Isr Med Assoc J 14:53-56

DeLong JH, Simpson KH, Wambre E et al (2011) Ara h 1-reactive T cells in individuals with peanut allergy. J Allergy Clin Immunol 127:1211-1218

Dhaliwal B, Pang MO, Yuan D et al (2013) Conformational plasticity at the IgE-binding site of the B-cell receptor CD23. Mol Immunol 56:693-697

Dowhower Karpa K, Paul IM, Leckie JA et al (2012) A retrospective chart review to identify perinatal factors associated with food allergies. Nutr J 11:87

Eigenmann PA, Oh JW, Beyer K (2011) Diagnostic testing in the evaluation of food allergy. Pediatr Clin North Am 58:351-362

Ewan PW (1996) Clinical study of peanut and nut allergy in 62 consecutive patients: new features and associations. BMJ 312:1074-1078

Faith A, Richards DF, Verhoef A et al (2003) Impaired secretion of interleukin- 4 and interleukin-13 by allergen-specific $\mathrm{T}$ cells correlates with defective nuclear expression of NF-AT2 and jun B: relevance to immunotherapy. Clin Exp Allergy 33:1209-1215

Fergusson DM, Horwood LJ, Shannon FT (1990) Early solid food feeding and recurrent childhood eczema: a 10-year longitudinal study. Pediatrics 86:541-546

Ford LS, Bloom KA, Nowak-Węgrzyn AH et al (2013) Basophil reactivity, wheal size, and immunoglobulin levels distinguish degrees of cow's milk tolerance. J Allergy Clin Immunol 131:180-186

Francis JN, Till SJ, Durham SR (2003) Induction of IL-10 + CD4 ${ }^{+}$ $\mathrm{CD}_{25}{ }^{+} \mathrm{T}$ cells by grass pollen immunotherapy. J Allergy Clin Immunol 111:1255-1261

Francis JN, James LK, Paraskevopoulos G et al (2008) Grass pollen immunotherapy: IL-10 induction and suppression of late responses precedes IgG4 inhibitory antibody activity. J Allergy Clin Immunol 121:1120-1125

Frazier AL, Camargo CA Jr, Malspeis S et al (2014) Prospective study of peripregnancy consumption of peanuts or tree nuts by mothers and the risk of peanut or tree nut allergy in their offspring. JAMA Pediatr 168:156-162

García Rodríguez R, Urra JM, Feo-Brito F et al (2011) Oral rush desensitization to egg: efficacy and safety. Clin Exp Allergy 41:1289-1296

Gokmen NM, Ersoy R, Gulbahar O et al (2012) Desensitization effect of preseasonal seven-injection allergoid immunotherapy with olive pollen on basophil activation: the efficacy of olive pollen-specific preseasonal allergoid immunotherapy on basophils. Int Arch Allergy Immunol 159:75-82

Halken S, Høst A (1996) Prevention of allergic disease. Exposure to food allergens and dietetic intervention. Pediatr Allergy Immunol 7(9 suppl):102-107

Hourihane JO, Aiken R, Briggs R et al (2007) The impact of government advice to pregnant mothers regarding peanut avoidance on the prevalence of peanut allergy in United Kingdom at school entry. J Allergy Clin Immunol 119:1197-1202

Husby S, Jensenius J, Svehag S (1985) Passage of undegraded dietary antigen into the blood of health. Quantification, estimation of size distribution and relation of uptake to levels of specific antibodies. Scand J Immunol 22:83-92

Itoh N, Itagaki Y, Kurihara K (2010) Rush specific oral tolerance induction in school-age children with severe egg allergy: one year follow up. Allergol Int 59:43-51

Jones SM, Pons L, Roberts JL et al (2009) Clinical efficacy and immune regulation with peanut oral immunotherapy. J Allergy Clin Immunol 124:292-300

Jutel M, Akdis M, Budak F et al (2003) IL-10 and TGF- $\beta$ cooperate in the regulatory $\mathrm{T}$ cell response to mucosal allergens in normal immunity and specific immunotherapy. Eur $\mathrm{J}$ Immunol 33:1205-1214

Karlsson MR, Rugtveit J, Brandtzaeg P (2004) Allergen-responsive $\mathrm{CD} 4{ }^{+} \mathrm{CD} 25^{+}$regulatory $\mathrm{T}$ cells in children who have outgrow cow's milk allergy. J Exp Med 199:1679-1688

Koplin JJ, Osborne NJ, Wake M et al (2010) Can early introduction of egg prevent egg allergy in infants? A population-based study. J Allergy Clin Immunol 126:807-813

Lack G, Fox D, Northstone K et al (2003) Factors associated with the development of peanut allergy in childhood. N Engl J Med 348:977-985

Ling EM, Smith T, Nguyen XD et al (2004) Relation of CD4 ${ }^{+}$ $\mathrm{CD} 25^{+}$regulatory $\mathrm{T}$-cell suppression of allergen-driven T-cell activation to atopic status and expression of allergic disease. Lancet 363:608-615

Longo G, Barbi E, Berti I et al (2008) Specific oral tolerance induction in children with very severe cow's milk-induced reactions. J Allergy Clin Immunol 121:343-347

Mansoor DK, Sharma HP (2011) Clinical presentations of food allergy. Padiatr Clin North Am 58:315-326

Martorell A, De la Hoz B, Ibáñez MD et al (2011) Oral desensitization as a useful treatment in 2-year-old children with cow's milk allergy. Clin Exp Allergy 41:1297-1304

Martorell A, Alonso E, Boné J et al (2013) Food allergy committee of SEICAP. Position document: IgE-mediated allergy to egg protein. Allergol Immunopathol 41:320-336

Metsälä J, Lundqvist A, Virta LJ et al (2013) Mother's and offspring's use of antibiotics and infant allergy to cow's milk. Epidemiology 24:303-309

Nakayamada S, Takahashi H, Kanno Y et al (2012) Helper T cell diversity and plasticity. Curr Opin Immunol 24:297-302

Narisety SD, Skripak JM, Steele P et al (2009) Open-label maintenance after milk oral immunotherapy for IgE-mediated cow's milk allergy. J Allergy Clin Immunol 124:610-612

Niggemann B, Staden U, Rolinck-Werninghaus C et al (2006) Specific oral tolerance induction in food allergy. Allergy 61:808-811

Nowak-Węgrzyn A, Muraro A (2011) Food allergy therapy: is a cure within reach? Pediatr Clin North Am 58:511-530

Oliphant CJ, Barlow JL, McKenzie AN (2011) Insights into the initiation of type 2 immune responses. Immunology 134:378-385

Pabs O, Mowat AM (2012) Oral tolerance to food protein. Mucosal Immunol 5:232-239 
Pajno GB, Caminiti L, Ruggeri P et al (2010) Oral immunotherapy for cow's milk allergy with a weekly up-dosing regimen: a randomized single-blind controlled study. Ann Allergy Asthma Immunol 105:376-381

Patriarca G, Nucera E, Roncallo C et al (2003) Oral desensitizing treatment in food allergy: clinical and immunological results. Aliment Pharmacol Ther 17:459-465

Peters RL, Gurrin LC, Dharmage SC et al (2013) The natural history of IgE-mediated food allergy: can skin prick tests and serumspecific IgE predict the resolution of food allergy? Int J Environ Res Public Health 10:5039-5061

Plewako H, Wosińska K, Arvidsson M et al (2006) Basophil interleukin 4 and interleukin 13 production is suppressed during the early phase of rush immunotherapy. Int Arch Allergy Immunol 141:346-353

Poole JA, Barriga K, Leung DY et al (2006) Timing of initial exposure to cereal grains and the risk of wheat allergy. Pediatrics 117:2175-2182

Prescott SL, Smith P, Tang M et al (2008) The importance of early complementary feeding in the development of oral tolerance: concerns and controversies. Pediatr Allergy Immunol 19:375-380

Rutkowski K, Dua S, Nasser S (2012) Anaphylaxis: current state of knowledge for the modern physician. Postgrad Med J $88: 458-464$

Sampson HA (2004) Update on food allergy. J Allergy Clin Immunol 113:805-819

Sansotta N, Piacentini GL, Mazzei F et al (2013) Timing of introduction of solid food and risk of allergic disease development: understanding the evidence. Allergol Immunopathol 41:337-345

Sausenthaler S, Heinrich J, Koletzko S et al (2011) Early diet and the risk of allergy: what can we learn from the prospective birth cohort studies GINIplus and LISAplus? Am J Clin Nutr 94(6 suppl):2012S-2017S

Scott CL, Aumeunier AM, Mowat AM (2011) Intestinal CD103 ${ }^{+}$ dendritic cells: master regulators of tolerance? Trends Immunol 32:412-419

Scurlock AM, Jones SM (2010) An update on immunotherapy for food allergy. Curr Opin Allergy Clin Immunol 10:587-593

Shamji MH, Durham SR (2011) Mechanisms of immunotherapy to aeroallergens. Clin Exp Allergy 41:1235-1246

Shamji MH, James LK, Durham SR (2011) Serum immunologic markers for monitoring allergen-specific immunotherapy. Immunol Allergy Clin North Am 31:311-323

Sharquie IK, Al-Ghouleh A, Fitton P et al (2013) An investigation into IgE-facilitated allergen recognition and presentation by human dendritic cells. BMC Immunol 14:54

Shreffler WG, Castro RR, Kucuk ZY et al (2006) The major glycoprotein allergen from Arachis hypogaea, Ara h 1 , is a ligand of dendritic cell-specific ICAM-grabbing nonintegrin and acts as a Th2 adjuvant in vitro. J Immunol 177:3677-3685
Shreffler WG, Wanich N, Moloney M et al (2009) Association of allergen-specific regulatory $\mathrm{T}$ cells with the onset of clinical tolerance to milk protein. J Allergy Clin Immunol 123:43-52

Sicherer SH, Sampson HA (2007) Peanut allergy: emerging concepts and approaches for an apparent epidemic. J Allergy Clin Immunol 120:491-503

Sicherer SH, Sampson HA (2010) Food allergy. J Allergy Clin Immunol 125(2 suppl 2):S116-S125

Sicherer SH, Munoz-Furlong A, Goodbold JH et al (2010) US prevalence of self-reported peanut, tree nut, and sesame allergy: 11-year follow-up. J Allergy Clin Immunol 125:1322-1326

Skripak JM, Nash SD, Rowley H et al (2008) A randomized, doubleblind, placebo-controlled study of milk oral immunotherapy for cow's milk allergy. J Allergy Clin Immunol 122:1154-1160

Sudo N, Sawamura S, Tanaka K et al (1997) The requirement of intestinal bacterial flora for the development of an IgE production system fully susceptible to oral tolerance induction. J Immunol 159:1739-1745

Urra JM, Garcia Rodriguez R, Feo Brito F et al (2012) Oral desensitization to egg enables $\mathrm{CD} 4{ }^{+} \mathrm{FoxP}^{+}$cells to expand in egg-stimulated cells. J Investig Allergol Clin Immunol 22:71-73

van Neerven RJ, Wikborg T, Lund G et al (1999) Blocking antibodies induced by specific allergy vaccination prevent the activation of $\mathrm{CD}^{+}{ }^{+} \mathrm{T}$ cells by inhibiting serum-IgE-facilitated allergen presentation. J Immunol 163:2944-2952

van Wijk F, Knippels L (2007) Initiating mechanisms of food allergy: oral tolerance versus allergic sensitization. Biomed Pharmacother 61:8-20

Varshney P, Jones SM, Scurlock AM et al (2011) A randomized controlled study of peanut oral immunotherapy: clinical desensitization and modulation of the allergic response. J Allergy Clin Immunol 127:654-660

Venter C, Arshad SH (2011) Epidemiology of food allergy. Pediatr Clin North Am 58:327-349

Venter C, Hasan Arshad S, Grundy J et al (2010) Time trends in the prevalence of peanut allergy: three cohorts of children from the same geographical location in the UK. Allergy 65:103-108

Vickery BP, Pons L, Kulis M et al (2010) Individualized IgE-based dosing of egg oral immunotherapy and the development of tolerance. Ann Allergy Asthma Immunol 105:444-450

Vickery BP, Chin S, Burks AW (2011) Pathophysiology of food allergy. Pediatr Clin North Am 58:363-376

Wachholz PA, Soni NK, Till SJ et al (2003) Inhibition of allergenIgE binding to $\mathrm{B}$ cells by $\mathrm{IgG}$ antibodies after grass pollen immunotherapy. J Allergy Clin Immunol 112:915-922

Wambre E, James EA, Kwok WW (2012) Characterization of $\mathrm{CD}^{+}{ }^{+} \mathrm{T}$ cell subsets in allergy. Curr Opin Immunol 24:700-706

Wang J, Sampson HA (2013) Oral and sublingual immunotherapy for food allergy. Asian Pac J Allergy Immunol 31:198-209

Zhou L, Chong MM, Littman DR (2009) Plasticity of CD4 ${ }^{+}$T cell lineage differentiation. Immunity 30:646-655 